\section{Barash Y., Hnennyi 0., Martseniuk L., Charkina T.}

\title{
COMPARISON OF TOURIST TRAFFIC BY RAILWAY AND AUTOMOBILE TRANSPORT AND METHODICAL APPROACH TO DETERMINING THE COSTS OF SUCH TRANSPORTATIONS
}

\begin{abstract}
Проведено порівняння залізничного та автомобільного туризму та визначено їх переваги та недоліки. Наведене порівняння вказує на високий потениіал першого за умови, якщо він буде використовувати сучасний комфортний рухомий склад. Остаточний вибір туристичних перевезень слід обгрунтовувати економічними розрахунками через тривалість життєвого ицклу інвестиційного проекту. При формуванні варіантів реалізащї проекту автори пропонують визначати прогнозні грошові потоки кожного сценарію та ймовірність їх реалізації.
\end{abstract}

ключові слова: туристичні перевезення, туристичні поїздки, залізничний транспорт, чистий грошовий потік, економічна ефективність, туристичний маршрут.

\section{Introduction}

The tourism industry is one of the highly-profitable industries in the world. In this context Ukraine has a great potential in terms of development of travel services market, because the country has hundreds of historical and cultural sites, potentially interesting for tourists and extensive railway and automobile transport networks. Tourism development is closely related to the development of tourist infrastructure facilities, as well as the development of transport infrastructure, as one of the most important conditions for tourist travel is to cross over the space.

It should be noted that today the state of infrastructure facilities and rolling stock of railway and automobile transport is quite neglected. Transport industry has not received adequate financing from the state for decades, which resulted in the current unsatisfactory situation.

The way out of situation is attracting the investments of domestic and foreign investors. Finding optimal contact points of the social interests of the state with economic interests of business structures is one of the main tasks of the present.

Relevance of the research. Tourist industry influences the key industries of economics, such as transport and communications, trade, hotels and restaurants, health care and agriculture. Tourism is closely connected with the use of historical and natural heritage, study of traditions and cultures of different countries and therefore is a good example of how to coordinate problem solving of economic growth and sustainable development.

Solving this problem requires a careful study of the existing possibilities and potential development of railway and automobile transport, identifying the use areas of one or another transport mode when organizing tourist traffic.

\section{The object of research and its technological audit}

Railways of many countries in the world use such service as railway tourism as a sustainable way to receive additional revenues. Travels by train attract both locals and foreigners. The railway excursions in old-fashioned cars on the narrow gauges are very popular. Among the successful railway tourist transportations are the following examples.

For example, in the USA operates the Georgetown railway, narrow gauge line only $7,2 \mathrm{~km}$ long ascends an elevation of 200 meters above the sea level. More than a century it is a very popular tourist attraction. Classic train with old-fashioned cars powered by steam locomotive traction carries passengers, gradually climbing the bridge of 30 meters height.

In India operates a narrow gauge mountain railway Nilgiri with a length 46 kilometers, connecting Mettupalayam and Udahanadalam. The travel takes 5 hours when going up and 3 hours when going down. Almost 46 kilometers of the railway pass through 208 turns, 16 tunnels and 250 bridges.

Another famous narrow-gauge railway in the world is the one, on which passes the tourist train «Bernina Express», the route Chur (Switzerland) - Tirano (Italy). Four-hour journey will bring great pleasure to the passengers, because at the distance of $127 \mathrm{~km}$ they face a big height difference.

Talyllyn Railway in Great Britain only 12 kilometers long connects Tywyn with the station «Nantes Guernol» that is beyond the village of Abergynolwyn. It was open in 1866 .

The railway between Thailand and Burma or «Death Railway», which was built during the World War II is very popular with tourists. More than 100000 people died during construction of this railway. The length of the route is $415 \mathrm{~km}$. The train when driving is almost 
pressed against the cliffs and crosses a few shaky wooden bridges. Tourists will get an unforgettable experience during the passage across the bridge over the river Kwai.

In Serbia one offers for tourists twice a day train travel «Nostalgia» at the 13-kilometer narrow-gauge railway between the stations Mokra Gora and Sharhan Vitas. During a 30-minute trip tourists will pass through 20 tunnels.

In Hungary there are narrow-gauge railways in cities Palhaza, Miskolc, Nyiregyhaza. Narrow-gauge network in Hungary is 380 kilometers. They pass through the mountains and valleys opening to tourists picturesque landscapes.

Railway transport in Spain runs on the tracks of four types: Iberian $(1668 \mathrm{~mm})$, standard $(1435 \mathrm{~mm})$, meter $(1000 \mathrm{~mm})$ and narrow-gauge one (914 and $600 \mathrm{~mm})$. The total length of the railway network is about 15,3 thousand kilometers, 1,9 thousand kilometers of which are the narrow gauge railways. For tourists are offered several types of tourist trains from superfast to the regional or local ones.

In England at tourists' disposal is the smallest operating narrow gauge railway in the world «Romney», with the gauge only $381 \mathrm{~mm}$. The route from the village Hythe to the settlement Dungeness with eight stations 22 kilometers long is popular among both, locals and foreigners.

The biggest narrow-gauge railway network is in Japan. Actually, it is a narrow gauge $(1067 \mathrm{~mm}$, the so-called Cape gauge) is the standard here. Thus, it does not work one of the main disadvantages of the narrow-gauge railways. However, the narrow gauge still restricts the speed of trains that is why the high-speed lines Shinkansen have the standard gauge $(1435 \mathrm{~mm})$.

In Argentina the most famous among the tourists is the so-called «Train to the Clouds», which overcomes the 940 kilometers across the Andes, connecting Chile with Argentina. During the travel the train passes 29 bridges, 21 tunnels and 13 viaducts. At this the train climbs high in the mountains to a height of 4220 meters above sea level.

If we return to the narrow-gauges of the former Soviet Union, the most famous is the operating narrow-gauge railway Gulbene - Aluksne in Latvia. In Kazakhstan remained a few short narrow-gauge railways. Kudemsk narrow-gauge railway is one of the few remaining in Russia. It connects Severodvinsk and the village White Lake in the Arkhangelsk region. Tourist train consists of the locomotive and two small cars, as well as two open wooden platforms equipped with seats. The train at a speed $30 \mathrm{~km} / \mathrm{h}$ passes villages, forests, and lakes. The most of operating narrow gauge railways are located in Belarus. Among the former Soviet republics only in Azerbaijan and Moldova there is not one single remained narrow-gauge railway.

In Ukraine operate only four narrow-gauge railways, located in Transcarpathian region. Restoration of the narrow-gauge railways in Ukraine can be a momentum for attracting investments into potentially attractive type of business, because in the developed world countries the railway tourist transportations bring stable income to the owners of railways. Attracting additional funds will help to renew rolling stock and railway infrastructure, since today, in terms of services provided to passengers, railway transport does not meet the European requirements.

\section{The aim and objectives of research}

The aim of the study is to give clear recommendations concerning the use area of the tourist traffic by railway and road transport, and offer a single methodological approach to compare costs for tourist traffic by different transport modes.

To achieve this aim there are following objectives:

1. To systematize the advantages and disadvantages of railway and automobile tourism and develop efficient areas of their use in this context.

2. To develop a methodical approach to determine the costs of the company that will organize transportations on the specific tourist route.

\section{Research of existing solutions of the problem}

Many domestic [1-11] and international [12-17] scientists have paid attention to the problems of development of transport infrastructure, rolling stock and the tourism industry.

In work [4] paid much attention to the classification of tourism types; among them the railway tourism is allocated. According to the author, the new essence of the concept «railway tourism» reveals differences of industry from the existing types of tourist travel organization, conditions and economic priority, which makes it possible to determine the industry characteristics and directions of development strategy formation of railway tourism. The author also proposed a methodical approach to determining the organization feasibility and competitiveness of railway travels in different directions, which is based on the definition and use of coefficients of direction intensity, the tour attractiveness and efficient travel cost and makes it possible to organize more competitive railway travels as compared to the others.

In addition, the work determines the factors of tourist trips competitiveness, which take into account the peculiarities of railway tourism organization that most of all influence the needs satisfaction of potential customers through emphasizing the most important factors [4].

The authors in their scientific work [7] identified the prospects of railway tourism in Ukraine on the Transcarpathian narrow-gauge lines. In particular, the working group analyzed the technical state of Borzhava narrow-gauge railway to implement the rehabilitation project for efficient functioning of mountain railways with the track gauge $750 \mathrm{~mm}$ in the Carpathian region with the possibility of joining to the extensive international tourist network in prospect. Within the framework of the on-site inspection the expert group found that the objects of track facilities, passenger infrastructure, rolling stock and auxiliary units involved in the functioning of the narrow-gauge railway are in disrepair and need significant renewals and capital repair. But the routes of passenger trains remain eligible for participation in the project of development of the railway tourism in Ukraine [7].

In scientific work [1] when analyzing transport infrastructure concluded that the transport component of the Ukrainian tourist potential in modern conditions helps to its strengthening only in the sense that the system of transport networks has a pronounced transit nature. So, a large number of areas provided with diverse recreational resources have good transport accessibility for tourists and excursionists, both domestic and foreign ones. Regarding the state of the transport infrastructure, in order to make it contribute to the efficient use and increase of the tourism 
potential, it is necessary to improve all its components both in quantitative and especially in qualitative plan. Moreover, the active involvement of different transport modes to the tourist services will make it possible to effectively develop different areas and types of tourism business, diversify the range of provided tourism services [1].

In work [6] emphasizes that for the development of tourism industry in Ukraine it is necessary to develop the transport component. The author focuses on the revival of railway transport, namely the renewal of infrastructure and rolling stock by private investors.

In [11] note that tourist objects are still unclaimed because of underdevelopment of infrastructure of tourist services and the infrastructure is not restored because of the lack of interest of investors, since the state does not stimulate them. Among the directions of the situation improvement in the Ukrainian market of tourist services the author proposes the following steps: infrastructure renewal, development of social tourism programs, improving the information policy, reconstruction of tourist objects and others.

In work [8] development of tourist routes one of the effective promising directions of the work for Ukrainian railways is considered. At the same time the author insists on compliance with the European standards of service quality, as only due to the high level services it is possible to enhance the competitiveness of railway transport and tourism industry and, consequently, to attract large number of tourists.

The authors in their scientific work [10] emphasizes that the successful development of the tourism industry is impossible without active influence of the state on the conditions of its functioning. State participation involves the following steps: lowering the price of investments in tourism projects, including loans at competitive interest rates, establishing tax incentives, protection from double taxation, sales, lease of land or the infrastructure facilities below the market price; direct subsidies, investments guarantees in order to attract foreign investors. In the system of investment activities of the market economy important economic and social value belongs to investments in the tourism industry. Taking into consideration the complex value of tourism (economic, ecological, cultural, recreational, etc.), and respectively the value of investments in this industry to ensure the sustainable development of the national economy, the concept of «tourism investments» represents all the types of material and intellectual valuables that are invested in the objects of entrepreneurship and other activities, which resulted in received income and economic growth on the society scale or achievement of the social positive effect. Accounting the growing importance of innovations and modern technologies for competitiveness promotion of tourist companies it is offered to distinguish according to the investment objects the real, financial, innovation, intellectual and educational investments. Involvement of educational investments will provide quality education and specialist training of innovation type.

The author in scientific work [3] proposed to use the term «tourism cluster of border territory». It should be understood as a voluntary association of tourist companies in the border area, state regulatory bodies and local government bodies, educational, scientific and financial institutions in order to increase the competitiveness of the regional tourism product and accordingly to improve the indicators of socio-economic growth of the region. During its determining it is taken into account the paradigm shift of the forming of regional competitiveness for tourism product by means of the integrated use of tourism resources in the border region. This allowed offering new approaches to their monitoring, evaluation and implementation.

4.1. Unresolved aspects of the problem. Each of the above mentioned scientists made a significant contribution to solving the problems of transport, tourism and sustainable development of the country. But factors influencing the advantages or disadvantages of railway and automobile tourism are still not exactly defined. There are no clear recommendations concerning the use area of the tourist traffic by railway and road transport, as well as there is no single methodological approach to compare costs for tourist traffic by different transport modes.

\section{Methods of research}

Theoretical and methodological basis of the article is the provision of economic theory, management theory, and corporate governance. System, diagnostic and optimization approaches are used. They are laid the foundations for a comprehensive study of railway tourism development strategy. To achieve this goal and solve certain tasks used: definitive and morphological analysis - to improve definitions and setting deadlines semantic structure of tourism; abstract dialectical and logical methods - to determine the evolution of theoretical approaches to ensure logic and research activities concerning railway tourism; synthesis and analysis - for the formation of theoretical positions management economic efficiency of railway tourism method of evaluation factors internal and external environment and methods of decision-making to select the organizational model of construction companies involved in rail tourism; observation of detail, grouping and summarizing - to define and systematize the main factors affecting the efficiency of rail tourism; method of market research and anonymous survey to determine the demand on Ukraine railway tourism methods of competition - to determine the competitive advantages of rail tourism; method of assessing the efficiency of real investment - to determine the amount of investment in the development of railway tourism organizational and administrative - to build an optimal model of management of tourist organizations; calculation method - to calculate the cost of rail transport and tourist services.

\section{Research results}

Comparison of two types of the tourist travels performed by railway and road transport is great interest. Each of these modes of transport has certain advantages and disadvantages. For example, railway tourism has the following advantages:

1. The main advantage of the railway transport is the association of hotel and restaurant services with the process of tourist transportations between different Ukrainian cities and tourist attractions. For this purpose tourist train involves special passenger dining cars, the amount of which 
is determined by the standard number of tourists in one car and compartment passenger cars of different comfort level with a full range of hotel services.

2. The number of inconvenient transportations through the tourist towns and the objects for relax and active rest is significantly reduced, as the trips to the places of morning and evening meals and stay in hotels are eliminated. In addition, the tourists fatigue during transfer transportations is reduced, and the satisfaction from tourist sightseeing tours on the contrary increases.

3. Due to elimination of time for transfer transportations, morning and evening meals, as well as the time for the rest in hotels, tourists can in addition view local tourist attractions, beautiful nature, reserves, castles and other peculiarities.

4. Travels by premium class buses provide only partial use of toilets, as there is no full comfort for maintenance of such toilets at the tourist routes. That is why it is necessary to make stops on the road for using outside toilets and rest.

5. Automobile tourism cannot provide full comfort for its customers, which involves shower, multi-channel television, refrigerators, rooms for laundry, drying and ironing clothes, mini bars, wardrobe, hairdressing salon.

6. The travel term by railway transport can far exceed the travel term by tourist buses, as the latter do not provide appropriate comfort.

At the same time, automobile tourism has some significant advantages over the railway tourism:

1. High mobility and ability to perform tourist travels in any area where you can find the roads with adequate quality of topping.

2. Only partially requires the use of transfer transportations to travel on certain automobile roads.

3. Sector of tourism services is much broader than that of railway transport, because it has a much larger network of highways.

4. Tourist buses can smoothly run the roads of the European countries, which is very difficult for railway transport as it is required the replacement of bogies for the track $1435 \mathrm{~mm}$.

However, both of the proposed types for tourist traffic have significant disadvantages:

1. Low speed, which does not exceeds $110 \mathrm{~km} / \mathrm{h}$ in average. This is considerably inferior to the air transport $850 \mathrm{~km} / \mathrm{h}$.

2. Railway and road transport (limited) can only be used within the continents.

3. Both types of tourist traffic pollute the environment in varying degrees. Automobile transport pollute the air most of all because it uses diesel fuel, the railway transport is more environmentally friendly because basically it uses electric traction. According to this factor, they greatly inferior to the marine tourism.

4. The limited term of the tourist travel by automobile and railway transport, which do not exceed 28 days, is significantly inferior to the marine tourism.

Below it is compiled a comparison table, which systematized the advantages and disadvantages of the railway and automobile tourism (Table 1).

Analyzing the above mentioned factors one can recommend the efficient use areas of railway and automobile tourism (Table 2).
Table 1

Factors influencing the advantages or disadvantages of railway and automobile tourism

\begin{tabular}{|l|c|c|}
\hline \multicolumn{1}{|c|}{$\begin{array}{c}\text { Factors influencing the advantages } \\
\text { or disadvantages of railway and automo- } \\
\text { bile tourism }\end{array}$} & $\begin{array}{c}\text { Mark of the factors belonging } \\
\text { to the advantage or disad- } \\
\text { vantage }\end{array}$ \\
\cline { 2 - 3 } & Advantage & Disadvantage \\
\hline $\begin{array}{l}\text { Association of hotel and restaurant services } \\
\text { with the process of transportation of tourists }\end{array}$ & + & - \\
\hline $\begin{array}{l}\text { Number of inconvenient transportations } \\
\text { through the tourist towns }\end{array}$ & + & - \\
\hline $\begin{array}{l}\text { Possibility to have a look at the local tour- } \\
\text { ist attractions, beautiful nature, reserves, } \\
\text { castles and other peculiarities }\end{array}$ & + & - \\
\hline Special toilets service while traveling & + & - \\
\hline Ensuring full confort for customers & + & - \\
\hline Term of the travel & + & - \\
\hline Possibility of tourist travel in any area & - & + \\
\hline Partial use of transfer transportations & - & + \\
\hline Sector of tourism services & - & + \\
\hline $\begin{array}{l}\text { Free run on the territories of the European } \\
\text { countries }\end{array}$ & - & + \\
\hline Low average motion speed $110 \mathrm{~km} / \mathrm{h}$ & - & - \\
\hline Transportations only within continents & - & - \\
\hline Environmentally friendly tourist traffic & + & - \\
\hline Term of tourist travel & + & - \\
\hline
\end{tabular}

Table 2

Recommended use areas of the tourist traffic by railway and by automobile transport

\begin{tabular}{|c|c|c|}
\hline $\begin{array}{l}\text { Type of the tourist } \\
\text { travel }\end{array}$ & $\begin{array}{l}\text { Recommended } \\
\text { transport mode }\end{array}$ & Nate \\
\hline \multicolumn{3}{|c|}{ One-day sightseeing tourism: } \\
\hline - across the country & Automobile & Tourist buses \\
\hline $\begin{array}{l}\text { - on the narrow } \\
\text { gauges }\end{array}$ & Railway & $\begin{array}{l}\text { Special rolling stock for the } \\
\text { narrow gauges }\end{array}$ \\
\hline \multicolumn{3}{|c|}{ Two-day weekend tourism } \\
\hline - across the country & Automobile & Tourist buses \\
\hline $\begin{array}{l}\text { - on the narrow } \\
\text { gauges }\end{array}$ & Railway & $\begin{array}{l}\text { Special rolling stock for the } \\
\text { narrow gauges }\end{array}$ \\
\hline \multicolumn{3}{|c|}{ Short-term tourism to 6 days } \\
\hline - across the country & $\begin{array}{l}\text { Automobile and } \\
\text { railway }\end{array}$ & $\begin{array}{l}\text { Buses of upper class } \\
\text { Special new railway rolling } \\
\text { stock }\end{array}$ \\
\hline $\begin{array}{l}\text { - on the narrow } \\
\text { gauges }\end{array}$ & Railway & $\begin{array}{l}\text { Special rolling stock for the } \\
\text { narrow gauges }\end{array}$ \\
\hline \multicolumn{3}{|c|}{ Medium-term tourism 7-12 days } \\
\hline - across the country & $\begin{array}{l}\text { Automobile and } \\
\text { railway }\end{array}$ & $\begin{array}{l}\text { Buses of upper class } \\
\text { Special new railway rolling } \\
\text { stock }\end{array}$ \\
\hline $\begin{array}{l}\text { - along the territory of } \\
\text { the European countries }\end{array}$ & Automobile & Buses of upper class \\
\hline \multicolumn{3}{|c|}{ Cruise tourism to 28 days } \\
\hline - with full comfort & Railway & $\begin{array}{l}\text { Special new rolling stock } \\
\text { including a full set of cars }\end{array}$ \\
\hline - with partial comfort & $\begin{array}{l}\text { Railway and } \\
\text { automobile }\end{array}$ & $\begin{array}{l}\text { Special new rolling stock in- } \\
\text { cluding a partial set of cars } \\
\text { Buses of upper class }\end{array}$ \\
\hline
\end{tabular}


The above mentioned comparison of the two types of tourist traffic by railway and automobile transport indicates the high potential of the former, provided it will use modern comfortable rolling stock and have in its structure not only the cars for tourist transportation, but also dining car, casino car, disco car (during the day game car for kids) and others. This set of cars should be recommended for cruise tourism with a period from 8 to 28 days, for shorter journeys the tourist train may not include casino car, disco car (during the day game car for kids) and others. But because of the absence of such rolling stock in Ukraine currently it is very difficult to implement this potential. For designing and manufacturing of these cars or their purchasing abroad significant means are needed.

The final choice of tourist traffic can be performed based on economic calculations by the method proposed in [2]

It offers to calculate net cash flow for each time interval from the period of the life cycle of investments by the formula (1).

$$
N C F=N P+A-C-\Delta W C+\Delta L T L,
$$

where $N C F$ - is a net cash flow for the own capital; $N P$ is net profit corresponding to the time interval; $C$ - is capital investments (increase of the fixed assets) of the corresponding time interval; $\triangle W C$ - is increase in working capital (own working assets) in the corresponding time interval; $\triangle L T L-$ is increase in long-term liabilities in the corresponding time interval.

Net profit of each time interval can be defined using the following formula:

$$
N P=R-E-A-I T,
$$

where $R$ - is current revenues of investment project; $E-$ is operating expenditures of the investment project without amortization charges; $A$ - is amortization charges; IT is income tax.

Combining the formulas (1) and (2) makes it possible to obtain the following formula (3) to determine the net cash flow:

$$
N C F=R-E-I T-C-\Delta W C+\Delta L T L .
$$

Revenue forecasting of the investment project related to the development of railway tourism can be based on the forecast of the volume of services provided to the consumers of tourism services, and the forecast of prices of the corresponding services. In this case, current revenues of the investment project can be defined by the formula (4).

$$
R=\sum_{i=1}^{n} Q_{i} \cdot P_{i}
$$

where $n$ - is the number of positions of the range of services; $Q_{i}-$ is the volumes of services of the $i$-th type from the range of services; $P_{i}-$ is the price of services of the $i$-th type from the range of services.

When forecasting the revenues it is necessary to take into account the fact that the current revenues of the investment project are equal to the expenditures of the consumers of tourism services. Therefore, the revenues can be determined using the relationship:

$$
R=G \cdot C \cdot \lambda,
$$

where $G$ - is the total number of resource days of the tourism services consumption within the investment project for the corresponding time interval; $C$ - is the average expenditures of the consumer for tourism services for one day; $\lambda-$ is the share of consumer's expenditures for the services provided to ensure the investment project.

To forecast the operating expenditures the following model can be used:

$$
E=F E+\sum_{i=1}^{n} Q_{i} \cdot z_{i}
$$

where $F E$ - is the conventionally fixed operating expenditures without amortization charges; $z_{i}$ is the specific variable operating expenditures without amortization charges related to the delivery of the $i$-th type of services per unit of the corresponding services (self-cost of the $i$-th type of services in terms of variable expenditures).

For a certain tourist route one can determine the current revenues of the investment project $R$ using the price of trip ticket $P T$ and the prospective number of tourists $N T$ that will use this travel in future.

In general terms the cost of the trip ticket when using the railway or automobile transport will include the following components:

$$
\begin{aligned}
& P T=C T T+C S S R+C S S A+C S S+C T r+ \\
& +C E+C H+C M+C A C+O C C,
\end{aligned}
$$

where CTT - is the cost of transportations by railway or automobile transport on the specific route, UAH. It includes all the costs of travel company to pay for services of access and use of railway infrastructure or automobile roads, the rent of rolling stock or buses (if they do not belong to the company); CSSR - is the costs for supplementary services of railway transport, which include the washing of rolling stock, maintenance of vacuum toilets, water supply of the rolling stock, pay for railway track for idle time of rolling stock, connection of cars to a power supply at the stations in tourist towns and others; CSSA - is the costs for supplementary services of automobile transport infrastructure, which include the buses washing, filling them with fuel, pay for parkings, UAH; CSS - is the costs for payment of supplementary tourist services, UAH. They include payments to the company servicing the dining cars, car bars or pantry, payments to the company that has a license for gambling, payments to animators working with children during the cruise, payments to stewards, conductors, locomotive crews, drivers and other workers serving tourists in rolling stock; $C T r$ - is the cost of transfer transportations and local tourist buses taking into account the services of guide, UAH. It also includes payment of bus rent for transportation of tourists from railway station or railway siding and back, $\mathrm{UAH}$; $C E-$ is the cost of excursions taking into account the services of guide, who shows local attractions, museums, beautiful nature, reserves, castles, local features etc., UAH; $\mathrm{CH}$ - is the costs for the services of hotels, motels, apartments, where will live tourists in tourist towns, UAH; $C M$ - is the costs for meals at local restaurants, cafes, and other establishments; $C A C$ - is the maintenance costs of the travel agencies, advertising companies, which help to promote the company and sell its travel tickets, UAH; $O C C$ - is the own costs of the 
travel company considering the costs for construction and maintenance of their facilities and buildings, UAH.

The cost of the travel ticket except the above mentioned components includes the estimated profit, which is defined in a percentage terms of the total costs, taking into account the demand for this type of tourist traffic.

This approach is based on accounting all complex of costs associated with the technological process of tourism services. It includes the costs for the process of transportation itself, delivery of additional services of infrastructure and rolling stock owners, pay for transfer transportations, services of hotels, restaurants, cafes, travel agencies, advertising organizations and own costs of travel company. It makes possible to determine the costs of travel package more accurately, taking into account the demand for this type of tourist traffic.

\section{SWOT-analysis of research results}

Strengths. As a result of the proposed measures one can expect increase of passenger traffic on the railroad, image improvement of the Ukrainian railways within the country and abroad, attraction of additional funds to renew the outdated infrastructure and rolling stock, restoration of the objects of cultural and historical significance, creation of new jobs, and restraining of migration processes in western Ukraine.

Weaknesses. For many years there was chronic underfunding rail industry by the state. As a result, the rolling stock is morally and physically obsolete. To increase the competitiveness of rail transport authors propose to develop railway tourism in Ukraine. But the main railway company of Ukraine - Open Joint Stock Company «Ukrainian Railways» - does not have the funds to purchase rolling stock and infrastructure upgrades.

Opportunities. The following factors can be attributed to the possibility of the development of railway tourism:

1. With the help of the private investor Ukrzaliznytsia will update the rolling stock, as well as tourism and transport infrastructure.

2. Residents of Ukraine will receive affordable form of recreation, because train travel is cheaper than a car overnight in a hotel.

3. Private investors will be able to profit from a new kind of business, on public-private partnership, because until now to private investors in railway transport business was closed. Railroad for many years was a monopoly in the provision of services in their area of service.

Threats. Unstable political and economic situation in the country, the imperfection of the legislative framework in the sphere of railway transport and tourism can restrain the desire of the private investor to invest in the development of railway tourism. In addition, given the low solvency of the population, there is a chance that for the ordinary citizen traveling on a tourist train will be too expensive. As a result, the private investor's income will fall sharply, and the payback period of the project will increase dramatically.

\section{Conclusions}

On the basis of conducted research it can be concluded that:

1. For the first time in Ukraine it is proposed the classification of narrow-gauge transfers and tourist travels depending on the travel purpose, type of rolling stock, travel term, and the service areas. This makes it possible to plan in advance the required number of the railcars and tourist trains for transportations of passengers, tourists, residents of the region, and service personnel depending on their number.

In our time, obsolete technology in rail transport, which are not developed and are not profitable, cannot attract investors for development of this area.

2. Conducted studies have shown that tourist traffic by railway transport has high potential, provided that it will use modern comfortable rolling stock and have in its structure not only the cars for tourist transportation, but also dining car, casino car, disco car (during the day game car for kids) and others. The above mentioned set of cars should be recommended for cruise travel with a period from 8 to 28 days, for shorter journeys the tourist train may not include casino car, disco car (during the day game car for kids) and others.

The final choice of tourist traffic may be justified by economic calculations using the method proposed by this article.

\section{References}

1. Butko, M. P. Transportna infrastruktura yak skladova turystychnoho potentsialu Ukrainy [Electronic resource] / M. P. Butko, N. O. Alieshuhina // Efektyvna ekonomika. - 2009. - № 3. Available at: \www/URL: http://www.economy.nayka.com.ua/ ?op $=1 \& z=62$. -28 April 2016 .

2. Hnennyi, O. M. Methodical approaches to assessment of economic efficiency of investments into development of tourist traffic by rail [Text] / O. M. Hnennyi // Proceedings of the Dnipropetrovsk National University of Railway Transport named after Academician V. Lazaryan «The Problems of the Transport Economics». - 2015. - № 10. - P. 7-14.

3. Hoblyk-Markovych, N. M. Pidvyshchennia investytsiinoi pryvablyvosti rehionu na osnovi formuvannia turystychnoho klasteru [Text] / N. M. Hoblyk-Markovych // Herald of Khmelnytskyi National University. - 2010. - Vol. 5, № 4 (166). - P. 76-79.

4. Derhousova, A. O. Formuvannia stratehii rozvytku zaliznychnoho turyzmu [Text]: PhD thesis / A. O. Derhousova. - Kharkiv, 2012. - 216 p.

5. Kozubova, N. V. Otsinka potentsialu vnutrishnoho rynku turystychnykh posluh [Text] / N. V. Kozubova. - Kharkiv, 2015. - 20 p.

6. Korobyova, R. Potential of development of railway tourism in Ukraine [Text] / R. Korobyova // Transportni systemy ta tekhnolohii perevezen. - 2015. - № 20. - P. 70-74.

7. Kuznetsov, V. G. Perspectives of Ukrainian railway tourism development on narrow-gauge lines of Zakarpattia [Text] V. G. Kuznetsov, P. O. Pshinko, I. V. Klimenko, A. V. Gumenyuk, S. M. Zahorulko // Science and Transport Progress. Bulletin of Dnipropetrovsk National University of Railway Transport. - 2015. - № 4 (58). - P. 23-33. doi:10.15802/ stp2015/49196

8. Novitska, I. V. Yevropeiskyi dosvid u rozvytku zaliznychnoho transportu i turystychnoi haluzi Ukrainy [Text] / I. V. Novitska // Visnyk ekonomiky transportu i promyslovosti. 2013. - № 41. - P. 114-117.

9. Ostapiuk, N. I. Koniunkturotvorni faktory turyzmu [Text] N. I. Ostapiuk // Modelling of Regional Economics. - 2010. № 3(1). - P. 127-133.

10. Stoika, V. O. Aktualni problemy ta perspektyvy rozvytku turystychnoi haluzi yak priorytetnoho napriamu investuvannia sotsialnoi sfery [Text] / V. O. Stoika // Naukovyi visnyk Chernihivskoho derzhavnoho instytutu ekonomiky i upravlinnia. - 2011. - № 1 (9). - P. 96-104.

11. Khaustova, V. Y. Problems of Development of Tourist Industry in Ukraine [Text] / V. Y. Khaustova, Y. F. Gorbatova // The Problems of Economy. - 2010. - № 2. - P. 28-33.

12. American-Rails.com [Electronic resource]. - Available at: \www/ URL: http://www.american-rails.com/gcry.html. - 28 April 2016. 
13. Scenic rail routes in France [Electronic resource]. - Available at: \www/URL: http://about-france.com/scenic-railways. htm. - 28 April 2016.

14. Brida, J. G. Tourism and transport systems in mountain environments: analysis of the economic efficiency of cableways in South Tyrol [Text] / J. G. Brida, M. Deidda, M. Pulina // Journal of Transport Geography. - 2014. - Vol. 36. - P. 1-11. doi:10.1016/j.jtrangeo.2014.02.004

15. Khanal, B. R. Tourism inter-industry linkages in the Lao PDR economy: an input-output analysis [Text] / B. R. Khanal, C. Gan, S. Becken // Tourism Economics. - 2014. - Vol. 20, № 1. P. 171-194. doi:10.5367/te.2013.0255

16. Pratt, S. Economic linkages and impacts across the talc [Text] S. Pratt // Annals of Tourism Research. - 2011. - Vol. 38, № 2. - P. 630-650. doi:10.1016/j.annals.2010.11.014

17. Forsyth, P. The impacts of Australia's departure tax: Tourism versus the economy? [Text] / P. Forsyth, L. Dwyer, R. Spurr, T. Pham // Tourism Management. - 2014. - Vol. 40. - P. 126136. doi:10.1016/j.tourman.2013.05.011

\section{СРАВНЕНИЕ ТУРИСТИЧЕСКИХ ЛЕРЕВОЗОК}

ЖЕЛЕЗНОДОРОЖНЫМ И АВТОМОБИЛЬНЫМ ТРАНСПОРТОМ И МЕТОДИЧЕСКОГО ПОДХОДА К ОПРЕДЕЛЕНИЮ РАСХОДОВ НА ДАННЫЕ ЛЕРЕВОЗКИ

Проведено сравнение железнодорожного и автомобильного туризма и определены их преимущества и недостатки. Указанное авторами сравнение указывает на высокий потенциал первого при условии, что он будет использовать современный комфортный подвижной состав. Окончательный выбор туристических перевозок следует обосновывать экономическими расчетами c учетом длительности жизненного цикла инвестиционного проекта. При формировании вариантов реализации проекта авторы предлагают определять прогнозные денежные потоки каждого сценария и вероятность их реализации.

Ключевые слова: туристические перевозки, туристические поездки, железнодорожный транспорт, чистый денежный поток, экономическая эффективность, туристический маршрут.

Barash Yurii, Doctor of Economical Sciences, Professor, Department of Accounting, Audit and Intellectual Property, Dnipropetrovsk National University of Railway Transport named after Academician V. Lazaryan, Dnipro, Ukraine, e-mail: ubarash@mail.ru, ORCID: http://orcid.org/0000-0001-5911-9805

Hnennyi Oleh, Doctor of Economic Sciences, Associate Professor, Department of Economics and Management, Dnipropetrovsk National University of Railway Transport named after Academician V. Lazaryan, Dnipro, Ukraine, e-mail: oleg_gnennij@mail.ru, ORCID: http://orcid.org/0000-0002-2944-5105

Martseniuk Larysa, PhD, Department of Economics and Management, Dnipropetrousk National University of Railway Transport named after Academician V. Lazaryan, Ukraine, e-mail: rwinform1@rambler.ru, ORCID: http://orcid.org/0000-0003-4121-8826

Charkina Tetiana, PhD, Department of Economics and Management Dnipropetrousk National University of Railway Transport named after Academician V. Lazaryan, Dnipro, Ukraine, e-mail: charkina@i.ua, ORCID: http://orcid.org/0000-0003-2916-9195 